Jurnal Geografi, Edukasi dan Lingkungan (JGEL) Vol. 5, No. 2, Juli 2021:92-100

P-ISSN: 2579-8499; E-ISSN: 2579-8510

Doi: https://doi.org/10.22236/jgel. v5i2.7032

Website: http://journal.uhamka.ac.id/index.php/jgel

\title{
Perubahan Kondisi Variasi Land Surface Temperature di Masa Pandemi Covid-19 (Studi Kasus: Kota Kediri, Jawa Timur)
}

\author{
Frandika Haris Nando ${ }^{1^{*}}$ \\ ${ }^{1}$ Jurusan Geografi, Fakultas Ilmu Sosial, Universitas Negeri Malang, Malang, Indonesia \\ *E-mail: frandika.haris.1807226@students.um.ac.id \\ Received: 0205 2021/ Accepted: 3006 2021/ Published online: 27072021
}

\begin{abstract}
ABSTRAK
Pandemi Covid-19 telah berdampak pada pemerintah Kota Kediri yang memberlakukan kebijakan pembatasan kegiatan aktivitas masyarakat guna menekan angka penyebaran Covid-19. Dampak kebijakan menimbulkan perubahan di berbagai aspek seperti kepadatan lalu lintas, interaksi sosial, dan operasional tempat umum masyarakat. Tujuan penelitian ini adalah untuk menganalisis perubahan suhu permukaan lahan di Kota Kediri saat sebelum dan sesudah adanya Pandemi Covid-19 dengan memanfaatkan teknologi remote sensing serta menggunakan metode analisis pada hasil pengolahan citra satelit. Jenis penelitian yang digunakan adalah penelitian deskriptif kuantitatif dengan hasil pengolahan citra. Data yang digunakan merupakan data sekunder hasil pengunduhan citra Landsat 8 OLI/TIRS di laman USGS. Teknik analisis data citra menggunakan software ArcMap 10.4 dengan tahap analisis Land Surface Temperature. Hasil penelitian menunjukkan bahwa suhu permukaan lahan mengalami penurunan selama awal pandemi Covid-19 pada April-Juni dikarenakan berkurangnya aktivitas masyarakat di luar ruang akibat kebijakan PPKM.
\end{abstract}

Kata Kunci: Land Surface Temperature, Covid-19, Kota Kediri

\begin{abstract}
The Covid-19 pandemic forced Kediri City goverments to impose a policiy of limiting community activities to suppress the spread of the corona virus. The impact of the policy causes changes in various aspects such as traffic congestion, social interaction, and the operation of public public places. The aim of this study was to analyze changes in ground surface temperature in Kediri City before and after the Covid-19 pandemic by utilizing remote sensing technology and using analytical methods on the results of satellite image processing. This type of research is descriptive quantitative research with image processing results. The data used is secondary data downloaded from Landsat 8 OLI/TIRS images on the USGS website. Image data analysis technique using ArcMap 10.4 software with stages of analysis of Ground Surface Temperature. The results showed that land surface temperatures decreased at the start of the Covid-19 pandemic in AprilJune due to reduced outdoor activities due to policies on limiting social activities.
\end{abstract}

Keywords: Land Surface Temperature, Covid-19, Kediri City 


\section{PENDAHULUAN}

Maret 2020, dunia dilanda pandemi penyakit secara global. Corona virus yang umum dikenal Covid-19 merupakan virus yang menjangkiti saluran pernapasan yang dapat menyebabkan pneumonia yang berujung kematian pada penderitanya (Handayani et al., 2020). Kondisi tersebut menuntut pemerintah mengambil berbagai langkah dan kebijakan guna meminimalisir penyebaran dan menekan angka kenaikan kasus terkonfirmasi Positif Covid-19. Salah satu kebijakan yang diberlakukan adalah memberlakukan sistem kerja dari rumah (work from home), sekolah dari rumah atau dalam jaringan (school form home), pembatasan jam buka dan tutup kegiatan ekonomi seperti pusat perbelanjaan toko, serta berbagai kebijakan yang membatasi aktivitas ke luar rumah (Yunus \& Rezki, 2020).

Salah satu pemerintah daerah kabupaten atau kota yang menjalankan kebijakan pembatasan aktivitas masyarakat berskala besar adalah Kota Kediri. Salah satu kota terbesar ketiga di Provinsi Jawa Timur setelah Kota Surabaya dan Kota Malang. Jumlah penduduk Kota Kediri mencapai 294.950 jiwa dengan luas administrasi sebesar $63,40 \mathrm{~km}^{2}$, sehingga kepadatan penduduknya mencapai 4.652 jiwa/ $\mathrm{km}^{2}$ (BPS Kota Kediri, 2020). Pertambahan penduduk mempengaruhi pertambahan luas area terbangun membuat aktivitas/mobilitas masyarakat tinggi. Kota Kediri menjadi pusat perdagangan dan jasa terbesar di selatan Jawa Timur. Kota Kediri di masa Pandemi Covid-19 memberlakukan kebijakan Pemberlakuan Pembatasan Kegiatan Masyarakat (PPKM) sebagai tindakan pencegahan penyebaran Covid-19.

Adanya pemberlakuan kebijakan PPKM, ditujukan untuk membatasi aktivitas masyarakat di luar rumah. Pembatasan tersebut dapat menimbulkan perubahan di berbagai aspek seperti kepadatan lalu lintas, interaksi sosial, dan operasional tempat umum masyarakat. Hal tersebut tentu dapat berdampak pada penurunan suhu permukaan suatu wilayah. Hal ini disebabkan oleh pembatasan kegiatan belajar di sekolah, penutupan kegiatan ekonomi seperti penutupan pusat perbelanjaan dan pertokoan, pembatasan kegiatan budaya dan kegiatan lain-lain di Kota Kediri.

Adanya pembatasan aktivitas masyarakat juga dapat menimbulkan perubahan suhu permukaan lahan (Putri et al., 2021). Disamping akibat pemanasan global, kenaikan suhu permukaan lahan didorong oleh kegiatan masyarakat yang menghasilkan emisi gas, selain itu aktivitas lalu lintas kendaraan dan naiknya jumlah kendaraan juga menjadi faktor pendukung kenaikan suhu permukaan lahan dari waktu ke waktu (Maishella et al., 2020). Studi suhu permukaan lahan membantu dalam perencanan pemanfaatan suatu area serta memudahkan dalam mengetahui distribusi spasial suhu permukaan suatu wilayah (Utomo et al., 2017).

Salah satu cara menghitung suhu permukaan lahan (Land Surface Temperature) dapat dilakukan melalui metode penginderaan jauh. Penginderaan jauh (remote sensing) didefinisikan sebagai teknik perolehan data dan informasi permukaan bumi tanpa bersentuhan langsung terhadap objek atau menggunakan suatu sensor. Penginderaan jauh memungkinkan pengguna melakukan pengkajian dan analisis objek atau daerah di permukaan bumi melalui akuisisi data citra satelit (Rahayu et al., 2015).

Oleh karena itu, berdasarkan kondisi inilah estimasi suhu permukaan lahan perlu dilakukan dan dikaji. Proses estimasi suhu permukaan lahan ini dilakukan dengan menggunakan data penginderaan jauh. Penggunaan data penginderaan jauh dalam identifikasi suhu permukaan lahan memberikan kemudahan untuk menghasilkan identifikasi dengan 
wilayah yang luas, biaya relatif murah, dan waktu yang singkat. Salah satu teknologi penginderaan jauh adalah memanfaatkan citra dari satelit Landsat.

Saluran band 10 yang berada pada saluran Thermal Infrared Sensor (TIRS) pada Landsat 8 dapat digunakan untuk kajian tidak langsung mengenai suhu permukaan lahan (Sampurno \& Thoriq, 2016). Pada penelitian ini digunakan data akuisisi citra satelit Landsat-8 OLI TIRS yang digunakan dalam perhitungan suhu permukaan lahan. Data yang digunakan pada penelitian ini merupakan akuisisi citra satelit pada Januari-September tahun 2020 atau data temporal yang kemudian diolah melalui Software ArcMap 10.4.

\section{METODE PENELITIAN}

Data dan Lokasi Penelitian

Lokasi studi kasus penelitian analisis variasi suhu permukaan lahan di Kota Kediri, Jawa Timur (Gambar 1). Data penelitian ini diperoleh dengan mengunduh Citra Landsat 8 melalui website Earth Explorer USGS. Data untuk menentukan sebaran suhu permukaan lahan pada penelitian adalah kanal multispektral (band 4 dan band 5) dan inframerah (band 10). Rentang waktu citra satelit yang digunakan pada penelitian ini adalah pada Bulan Januari sampai Maret yang mewakili sebelum masa PPKM, dan Bulan April sampai Juni 2020 yang mewakili awal saat pemberlakuan PPKM, dan pada Bulan Juli sampai September yang mewakili setelah pemberlakuan PPKM. Sementara itu, untuk data batas wilayah Kota Kediri, Jawa Timur yang di unduh melalui situs website Geoportal Kota Kediri (http://kedirikota.inasdi.or.id/).

\section{Jenis Penelitian}

Penelitian ini menggunakan pendekatan deskriptif kuantitatif dengan melakukan pengolahan citra digital dengan menggunakan aplikasi berbasis remote sensing dan aplikasi berbasis Geography Information System seperti ArcGIS (Nofrizal, 2018).

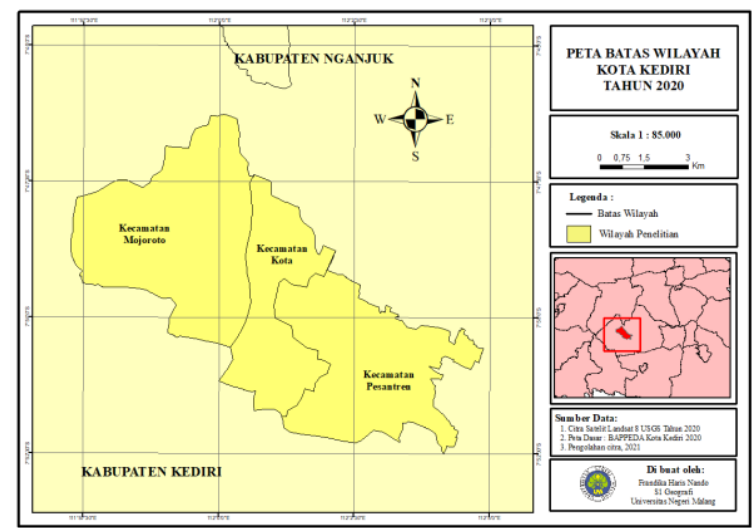

Gambar 1. Peta Batas Kota Kediri, 2020 Sumber: Penulis, 2021

\section{Metode Pengolahan dan Analisis Data}

Pengolahan data dalam penelitian suhu permukaan lahan, data yang digunakan merupakan Landsat-8 OLI. TIRS yaitu data reflektan citra Landsat- 8 yang telah terkalibrasi sensor (U.S. Geological Survey, 2019). Pengolahan suhu permukaan lahan dilakukan melalui beberapa tahap diantaranya: (1) Perhitungan dari nilai brightness menjadi radiance, (2) Radiance menjadi suhu permukaan (Kelvin), dan (3) Konversi suhu menjadi celcius.

Perhitungan spektral radian (radiance) dilakukan dengan persamaan berikut:

$$
L \lambda=M \mathrm{~L} \times Q \mathrm{cal}+A \mathrm{~L}
$$

Dimana $\mathrm{L} \lambda=$ spektral radian, $\mathrm{ML}=$ faktor skala perkalian, Qcal = nilai piksel produk standar (DN) yang dikuantisasi dan dikalibrasi, dan $\mathrm{AL}=$ faktor skala penambah. Dalam perubahan nilai spektral radian ke suhu permukaan lahan (Kelvin), dilakukan melalui persamaan berikut:

$$
\mathrm{T}=\frac{\mathrm{K} 2}{L \lambda} \frac{(\underline{\mathrm{K} 1})}{L \lambda}
$$


Dimana $\mathrm{T}=$ Suhu (dalam Kelvin), $\mathrm{L} \lambda=$ spektral radian, $\mathrm{K} 1=$ konstanta konversi termal band spesifik dari metadata, dan $\mathrm{K} 2$ = termal band-spesifik konversi konstan dari metadata. Untuk mendapatkan suhu permukaan lahan dalam satuan celcius, dilakukan konversi dengan persamaan:

$$
T T 2=T T-273,15
$$

Dimana $\mathrm{T} 2=$ suhu permukaan lahan (dalam Kelvin) dan $\mathrm{T} 2=$ suhu permukaan lahan (dalam Celcius). Seluruh algoritma tersebut diolah dalam software ArcMap, kemudian dilakukan perhitungan rata-rata setiap algoritma untuk mendapatkan nilai rata-rata pada rentang waktu yang dipilih. Alur penelitian disajikan pada Gambar 2.

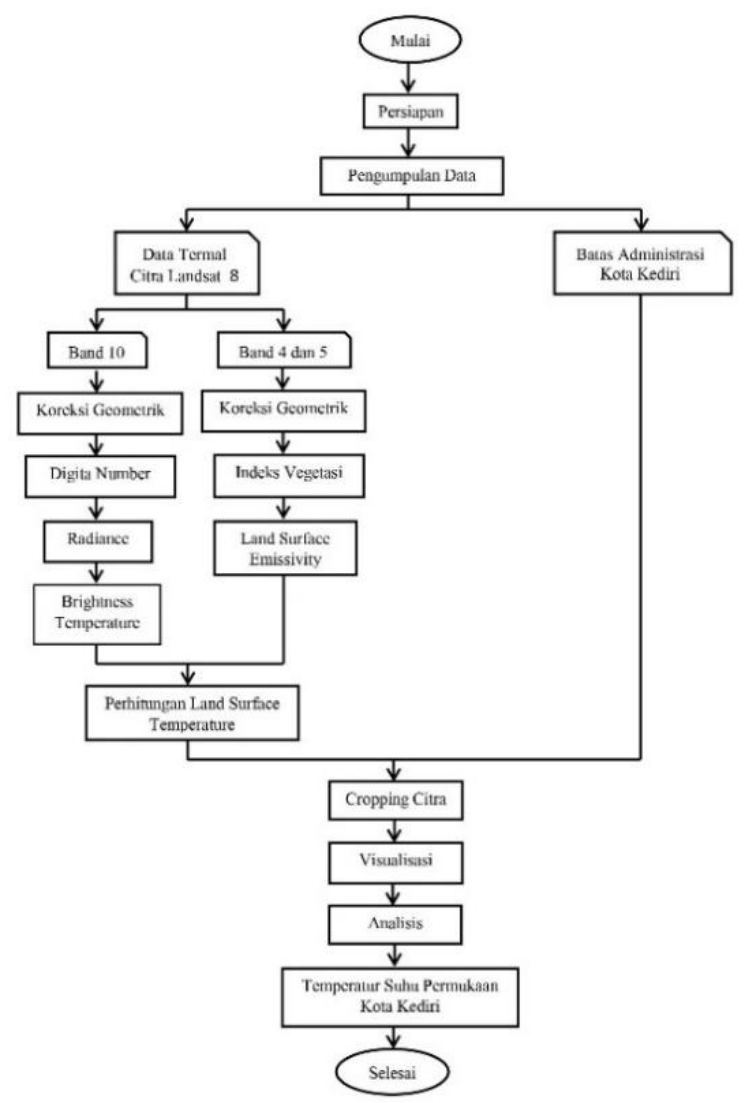

Gambar 2. Diagram Alur Penelitian

Sumber: Penulis, 2021

\section{HASIL DAN PEMBAHASAN}

Pada studi sebelumnya menunjukkan bahwa suhu permukaan lahan cenderung meningkat secara temporal dikarenakan adanya perubahan tutupan lahan, pertumbuhan fisik kota dan peningkatan jumlah penduduk (Singh et al., (2017), Walawender et al., (2014) dan Zhan et al., (2015). Namun, pada penelitian ini menunjukkan hasil temuan yang signifikan di mana rata-rata suhu permukaan lahan atau land surface temperature mengalami penurunan selama periode waktu tertentu, yang disebabkan oleh berkurangnya aktivitas antropogenik atau manusia di suatu wilayah.

Salah satu aktivitas antropogenik ialah meningkatnya jumlah penduduk dampak dari kegiatan ekonomi yang massif mendorong bertambahnya lahan terbangun pemukiman dan menyebabkan tingginya tingkat kepadatan penduduk di suatu wilayah (Yusrina et al., 2018). Kepadatan penduduk dalam penyebaran Covid-19 di Indonesia tergolong tinggi hal ini dikarenakan kawasan perkotaan yang memiliki kepadatan penduduk yang tinggi dibanding daerah pinggiran kota atau hinterland akan menyebabkan rantai penyebaran penyakit atau virus lebih cepat dan kompleks akibat massifnya aktivitas antropogenik (Shofi et al., 2021).

Untuk mengurangi transmisi penyebaran Covid-19, pemerintah daerah di berbagai wilayah Indonesia menerapkan kebijakan pembatasan sosial untuk mengurangi kegiatan sosial ekonomi. Salah satunya Kota Kediri, Jawa Timur yang menjadi lokasi studi kasus penelitian. Kebijakan tersebut mempengaruhi mobilitas masyarakat di Kota Kediri. Kebijakan tersebut selain menyebabkan berkurangnya aktivitas antropogenik namun juga berdampak pada kesehatan lingkungan seperti perubahan variasi suhu permukaan lahan di Kota Kediri, Jawa Timur. 


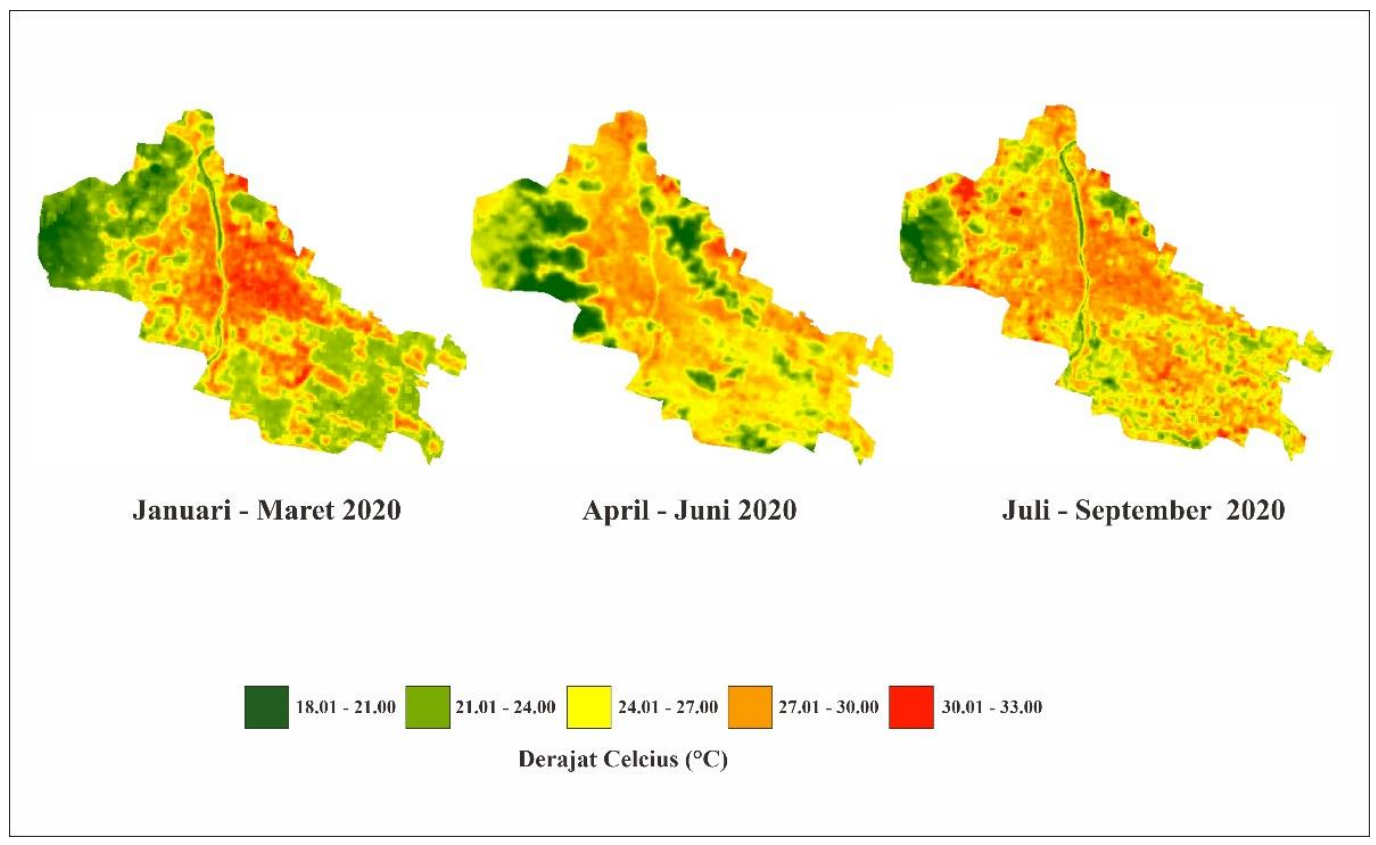

Gambar 3. Variasi Spasial Temporal LST Sumber Penulis, 2021

Penelitian ini melihat dinamika perubahan suhu permukaan lahan di masa pandemi Covid-19, dilakukan pula analisis Land Surface Temperature (LST) baik pada periode sebelum dan saat terjadinya pandemi Covid-19. Dapat dilihat pada Gambar 3 menunjukkan bahwa terjadi perubahan suhu permukaan lahan (land surface temperature) selama 9 bulan. Hal ini terlihat pada Januari-Maret di dominasi warna merah, oranye dan kuning (Gambar 3). Dengan warna merah yang mengindikasikan memiliki suhu lebih tinggi berada di pusat Kota yakni Kecamatan Kota. Sedangkan warna oranye dan hijau berada di pinggiran pusat kota.

Kecamatan Kota menjadi daerah dengan wilayah lahan terbangun tertinggi di Kota Kediri (Gambar 4). Hal ini karena Kecamatan Kota sebagai pusat kegiatan dan Central Business District (CBD) Kota Kediri. Mengingat Kecamatan Kota banyak berdiri kawasan aktivitas manusia seperti pusat industri, pusat perbelanjaan dan pusat perkantoran. Hal ini sejalan dengan kawasan terbangun cenderung memiliki suhu yang relatif tinggi dibanding kawasan non-terbangun dikarenakan faktor permukaan tanah itu sendiri dan aktivitas antropogenik yang dilakukan di kawasan terbangun (Shahmohamadi et al., 2011). Mengingat sebagian besar wilayah Kota Kediri merupakan lahan terbangun, dengan luasan berikut $67,42 \% \quad\left(42,75 \quad \mathrm{Km}^{2}\right)$ wilayah Kota Kediri telah menjadi lahan terbangun dan sisanya $29,76 \% \quad(18,87$ $\mathrm{Km}^{2}$ ) merupakan lahan non terbangun (vegetasi) dan badan air sungai 2,82\% $\left(1,78 \mathrm{Km}^{2}\right)$ (Tabel 3).

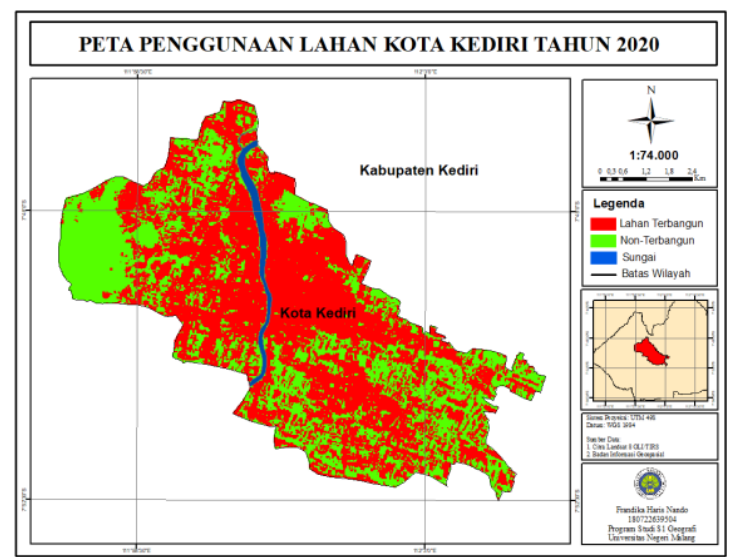

Gambar 4. Peta Land Use Kota Kediri Sumber: Penulis, 2020 
Tabel 3. Tutupan Lahan Kota Kediri 2020

\begin{tabular}{clcc}
\hline No & Lahan & Luas $\left(\mathbf{K m}^{2}\right)$ & Persentase \\
\hline 1 & Terbangun & 42,75 & $67,42 \%$ \\
\hline 2 & $\begin{array}{l}\text { Non- } \\
\text { Terbangun }\end{array}$ & 18,87 & $29,76 \%$ \\
\hline 3 & Badan Air & 1,78 & $2,82 \%$ \\
\hline & TOTAL & 63,41 & $100 \%$ \\
\hline
\end{tabular}

Sumber: Penulis, 2021

Suhu permukaan lahan menunjukkan pola yang sejalan dengan pola tutupan lahan terbangun. Suhu permukaan tinggi disebabkan oleh tutupan lahan yang terbangun lebih tinggi dibandingkan dengan tutupan vegetasi yang rendah. Suhu permukaan lahan terendah di Kota Kediri berada di daerah Kecamatan Mojoroto. Hal ini disebabkan karena wilayah Kecamatan Mojoroto masih banyak tutupan vegetasi yang rapat karena terdapat kawasan hutan gunung Klotok-Wilis dan dilalui badan sungai Brantas.

Tutupan hutan dan badan air cenderung memperlihatkan suhu permukaan lahan yang relatif rendah daripada kawasan terbangun. Hal ini dikarenakan kemampuan menahan yang dimiliki oleh badan air dan vegetasi untuk melakukan pendinginan evaporatif. Tutupan lahan dengan kelembaban seperti vegetasi hutan dan badan air meningkatkan fluks kalor laten dan menghambat aliran kalor sensibel. Sedangkan daerah perkotaan yang kering memperbesar aliran kalor sensibel dan menghambat fluks kalor laten (Shahmohamadi et al., 2011).

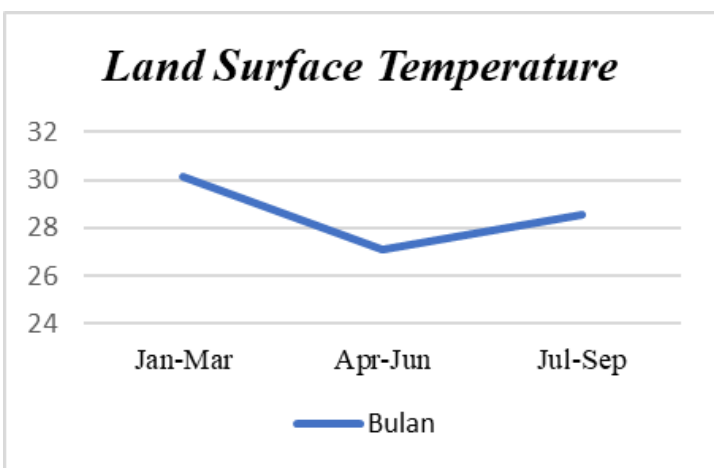

Gambar 5. Grafik LST Kota Kediri Sumber: Penulis, 2021
Tabel 4. Suhu Permukaan Lahan Rata-rata pada Tahun 2020

\begin{tabular}{clc}
\hline No & Bulan & Suhu $\left({ }^{\circ} \mathbf{C}\right)$ \\
\hline $\mathbf{1}$ & Januari-Maret & 30,16 \\
\hline $\mathbf{2}$ & April-Juni & 27,12 \\
\hline $\mathbf{3}$ & Juli-September & 28,56 \\
\hline \multicolumn{2}{l}{ Sumber: Penulis, 2021}
\end{tabular}

Tabel 5. Luasan Suhu Permukaan Lahan

\begin{tabular}{lcccc} 
No & Suhu $\left({ }^{\circ} \mathbf{C}\right)$ & \multicolumn{3}{c}{ Bulan $\left(\mathbf{K m}^{\mathbf{2}}\right)$} \\
\cline { 3 - 5 } & & $\mathbf{1 - 3}$ & $\mathbf{4 - 6}$ & $\mathbf{7 - 9}$ \\
\hline A & $18,01-21$ & 8,89 & 11,61 & 6,23 \\
\hline B & $21,01-24$ & 15,65 & 7,58 & 7,89 \\
\hline C & $24,01-27$ & 13,94 & 24,38 & 21,62 \\
\hline D & $27,01-30$ & 13,44 & 12,41 & 18,97 \\
\hline E & $30,01-33$ & 11,49 & 7,43 & 8,70 \\
\hline
\end{tabular}

Sumber: Penulis, 2021

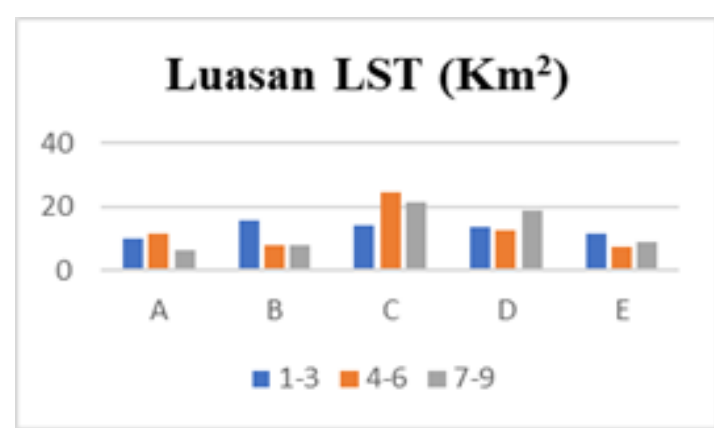

Gambar 6. Grafik Perubahan Luasan LST Sumber: Penulis, 2021

Selama bulan Januari-Maret ratarata suhu di Kota Kediri berada di kisaran $30,16^{\circ} \mathrm{C}$ (Tabel 4). Selama Januari-Maret 2020 luasan wilayah yang berada di suhu lembab yakni $24-33^{\circ} \mathrm{C}$ seluas $38,87 \mathrm{Km}^{2}$ atau 61,29\% (Tabel 5). Hal itu menunjukan bahwa tingkat mobilitas masyarakat masih tergolong tinggi sebelum pemerintah mengumumkan kasus pertama positif Covid dan pembatasan akibat pandemi Covid-19. Suhu permukaan lahan di Kota Kediri selama awal pandemi Covid-19 April-Juni 2020 menunjukan tren penurunan suhu permukaan (Gambar 5).

Pada April-Juni mengalami penurunan suhu cukup signifikan yakni $3,04^{\circ} \mathrm{C}$ dibandingkan Januari-Maret. Ratarata suhu April-Juni adalah $27,12^{\circ} \mathrm{C}$ (Tabel 4). Hal ini disebabkan oleh pemerintah Kota Kediri memberlakukan Pembatasan Kegiatan Masyarakat (PPKM) selama tiga 
bulan terhitung sejak April sampai Juni tahun 2020. Dampak pembatasan tersebut terlihat pada persebaran suhu, pada peta menunjukkan bahwa zona yang memiliki suhu tinggi dengan digambarkan warna merah sangat sedikit. Warna pada bulan April-Juni di dominasi warna oranye, kuning dan hijau (Gambar 3). Untuk wilayah pusat Kota Kediri yakni Kecamatan Kota yang menjadi pusat kegiatan mengalami penurunan suhu. Pada umumnya peta suhu permukaan lahan Kota Kediri pada bulan April-Juni mengalami penurunan suhu (Gambar 3).

Hal ini memungkinan dari kebijakan PPKM seperti adanya pengurangan aktivitas manusia di luar rumah, sehingga terjadi pengurangan volume kendaraan bermotor di jalanan, transportasi umum serta kegiatan ekonomi juga berhenti dengan penutupan Mall dan pusat pertokoan dengan tujuan mengurangi kerumuman masyarakat yang berpotensi menularkan Covid-19. Pembatasan aktivitas manusia tersebut dapat menurunkan suhu permukaan lahan di Kota Kediri cukup signifikan. Kenaikan rata-rata suhu permukaan lahan di Kota Kediri mulai terjadi pada Juli-September dengan rata-rata $28,56^{\circ} \mathrm{C}$ atau mengalami kenaikan $1,44^{\circ} \mathrm{C}$ dibandingkan bulan April - Juni (Tabel 4). Hal ini terlihat pada bulan Juli-September di dominasi warna oranye dan kuning (Gambar 3). Penyebab kenaikan suhu tersebut dapat diketahui dari pelonggaran pembatasan aktivitas masyarakat, dengan dibukanya kembali pusat ekonomi perdagangan seperti toko, mall, pasar perdagangan serta perkantoran dengan menerapkan protokol kesehatan Covid-19 yang ketat. Membuat masyarakat kembali melakukan kegiatan seperti sebelum pandemi.

Hal tersebut dapat di lihat pada peta yang menunjukkan warna kuning dan oranye mulai dominan dan hampir merata di seluruh wilayah Kota Kediri (Gambar 3). Dari peta tersebut terlihat bahwa mulai terjadi pemulihan aktivitas masyarakat dan menuju era normal baru pasca Covid-19. Memang diakui Covid-19 telah membawa dampak buruk terhadap sektor kehidupan secara menyeluruh, namun dalam hal ini setidaknya membawa pengaruh baik bagi ekosistem setempat dengan berkurangnya aktivitas manusia yang mencemari lingkungan terutama polusi udara kendaraan bermotor penyebab pencemaran lingkungan dan membahayakan saluran pernapasan manusia. Turunnya Suhu permukaan lahan di masa pandemi Covid19 menjadi sebuah momentum untuk mengurangi pemanasan global secara massif (Rizi et al., 2019).

\section{KESIMPULAN}

Kesimpulan dari hasil penelitian ini adalah bahwa terjadi perubahan kondisi variasi suhu permukaan lahan di Kota Kediri di masa pandemi Covid-19. Terlihat dari sebelum pandemi pada Januari-Maret 2020, suhu rata-rata di Kota Kediri berkisar $30,16^{\circ} \mathrm{C}$. Kenaikan suhu permukaan lebih disebabkan pada aktivitas manusia dan tutupan lahan terbangun yang masif terbanding terbalik dengan tutupan vegetasi yang rendah. Pada saat awal pandemi Covid-19, pemerintah Kota Kediri menerapkan kebijakan pembatasan aktivitas manusia berupa (Pemberlakuan Pembatasan Kegiatan Masyarakat (PPKM). Kebijakan tersebut ternyata berdampak pada penurunan mobilitas masyarakat karena penutupan pusat ekonomi dan sosial budaya masyarakat. Suhu permukaan pada awal pandemi bulan April-Juni suhu permukaan berada di nilai $27,12^{\circ} \mathrm{C}$ atau turun $3,04^{\circ} \mathrm{C}$ dibanding bulan Januari-Maret. Pada bulan Juli-September kenaikan suhu mulai terjadi dengan suhu rata-rata $28,56{ }^{\circ} \mathrm{C}$ atau mengalami kenaikan $1,44^{\circ} \mathrm{C}$ dibandingkan bulan April-Juni. Hal ini diakibatkan oleh pelonggaran kegiatan masyarakat saat Covid-19 dengan pembukaan sektor jasa perdagangan Kota Kediri, Jawa Timur. 


\section{DAFTAR PUSTAKA}

BPS, K. K. (2020). Kota Kediri dalam Angka 2020. Kota Kediri: BPS Kota Kediri Publisher.

Handayani, D., Hadi, D. R., Isbaniah, F., Burhan, E., \& Agustin, H. (2020). Penyakit Covid-19 2019. Jurnal Respirologi Indonesia, 40(2), 119129.

Maishella, A., Dewantoro, B. E. B., \& Aji, M. A. P. (2020). Correlation Analysis of Urban Development and Land Surface Temperature Using Google Earth Engine in Sleman Regency, Indonesia. IOP Conference Series: Earth and Environmental Science, 540(1). https://doi.org/10.1088/17551315/540/1/012018.

Nofrizal, A. Y. (2018). Identifikasi Urban Heat Island di Kota Solok menggunakan Algoritma Landsat- 8 OLI Landsurface Temperature. Media Komunikasi Geografi, 19(1), 31-41. https://doi.org/10.23887/mkg.v19i1.1 3755.

Putri, D. P. D., Sarfina, N., \& Kodong, F. R. (2021). Analisis Variasi Suhu Permukaan Tanah dan Gas Nitrogen Dioksida di Masa Pandemi Covid-19 (Studi Kasus: Kota Semarang). 1(2), 31-38.

Rahayu, L., Subiyanto, S., \& Yuwono, B. (2015). Kajian Pemanfaatan Data Penginderaan Jauh Untuk Identifikasi Objek Pajak Bumi Dan Bangunan (Studi Kasus : Kecamatan Tembalang Kota Semarang). Jurnal Geodesi Undip, 4(1), 20-31.

Rizi, U. F., Suradi, Sunaryo, Agus, A., Ahmad, M., Kusumaningtyas, S. D. A., Nurhayati, H., Khoir, A. N., Sucianingsih, C., \& W, N. F. P. (2019). Analisis Dampak Diterapkannya Kebijakan Working From Home Saat Pandemi Covid-19 Terhadap Kondisi Kualitas Udara Di Jakarta. Jurnal Meteorologi
Klimatologi dan Geofisika, 6 (3), 614. http://doi.org/10.36754/jmkg.v6i3 Sampurno, R. M., \& Thoriq, A. (2016). Klasifikasi Tutupan Lahan Menggunakan Citra Landsat 8 Operational Land Imager (OLI) di Kabupaten Sumedang. Jurnal Teknotan, 10(2), 61-70. https://doi.org/10.1016/s03767388(0 0)85017-6.

Shahmohamadi, P., Che-Ani, A. I., Maulud, K. N. A., Tawil, N. M., \& Abdullah, N. A. G. (2011). The Impact of Anthropogenic Heat on Formation of Urban Heat Island and Energy Consumption Balance. Urban Studies Research, 2011, 1-9. https://doi.org/10.1155/2011/497524.

Shofi, T., Rahmadani, A., \& Noor, D. M. M. (2021). Analisis Hubungan Kepadatan Penduduk dengan Pola Penyebaran COVID-19 Provinsi DKI Jakarta menggunakan Regresi Robust. 1(2), 51-60.

Singh, P., Kikon, N., \& Verma, P. (2017). Impact of Land use Change and Urbanization on Urban Heat Island in Lucknow City, Central India. A Remote Sensing Based Estimate. Sustainable Cities and Society, 32, 100-114.

https://doi.org/https://doi.org/10.1016 /j.scs.2017.02.018.

U.S. Geological Survey. (2019). Landsat 8 Data Users Handbook. Sioux Falls:EROS.

Utomo, A., Suprayogi, A., \& Sasmito, B. (2017). Analisis Hubungan Variasi Land Surface Temperature Dengan Kelas Tutupan Lahan Menggunakan Data Citra Satelit Landsat (Studi Kasus: Kabupaten Pati). Jurnal Geodesi Undip, 6(2), 71-80.

Walawender, J. P., Szymanowski, M., Hajto, M. J., \& Bokwa, A. (2014). Land Surface Temperature Patterns in the Urban Agglomeration of Krakow (Poland) Derived from Landsat- 
7/ETM+ Data. Pure and Applied Geophysics, 171(6), 913-940. https://doi.org/10.1007/s00024-0130685-7.

Yunus, N. R., \& Rezki, A. (2020). Kebijakan Pemberlakuan Lockdown Sebagai Antisipasi Penyebaran Corona Virus Covid-19. SALAM: Jurnal Sosial Dan Budaya Syar-I, 7(3), 227-238. https://doi.org/10.15408/sjsbs.v7i3.1 5048.

Yusrina, F. N., Sari, M. I., Chomsa, G., Hudaya, A., Hidayat, D. W., Jordan, E., \& Febriyanti, D. (2018). Analisis Pola Permukiman Menggunakan Pendekatan Nearest Neighbour Untuk Kajian Manfaat Objek Wisata Di Kecamatan Prambanan Kabupaten Klaten. Jurnal Geografi, Edukasi Dan Lingkungan, 2(1), 46-55.

Zhan, Q., Meng, F., \& Xiao, Y. (2015). Exploring the relationships between land surface temperature, ground coverage ratio and building volume density in an urbanized envronment. International Archives of the Photogrammetry, Remote Sensing and Spatial Information Sciences ISPRS Archives, 40(7W3), 255-260. https://doi.org/10.5194/isprsarchivesXL-7-W3-255-2015. 